\title{
Physicochemical Assessment of Broiler Chickens Fed Diets Supplemented with a Mixture of Ginger, Garlic and Cinnamon
}

\section{*IDOKO, AS; ZAHARADDEEN, A; IMAM, NU; NURA, S; ABDULAZEEZ, B; SUNDAY, H; UGWU, KU; OLAIYA, HA}

\author{
Department of Biochemistry, Federal University Dutsinma, Katsina state, Nigeria \\ *Corresponding Author Email: asidoko1@gmail.com; Tel: +2348060682678
}

\begin{abstract}
Some physicochemical changes in broiler chickens fed diets supplemented with a mixture of ginger, garlic and cinnamon was evaluated. During starter phase, 150 broiler chicks were divided into groups A and $\mathrm{B}$ of 75 birds each, and were randomly fed diets 1 and 2 respectively for 3 weeks. The average weekly weight gain by the chickens maintained on the mixed spices supplemented $\operatorname{diet}(235.15 \pm 15.55 \mathrm{~g})$ was significantly lower $(\mathrm{p}<0.05)$ compared with the weight gain by the control $(274.26 \pm 20.23 \mathrm{~g})$ in the Starter phase. In the Finisher phase, group A was sub-divided into groups $\mathrm{C}$ and $\mathrm{D}$ while group $\mathrm{B}$ was subdivided into groups $\mathrm{E}$ and $\mathrm{F}$ and fed for additional 3 weeks. The average weekly weight gain by groups $\mathrm{C}(242.31 \pm 4.97 \mathrm{~g}), \mathrm{D}(282.46 \pm 15.04 \mathrm{~g}), \mathrm{E}(260.14 \pm 81.11 \mathrm{~g})$ and $\mathrm{F}$ $(236.67 \pm 24.29 \mathrm{~g})$ did not vary significantly. The evaluated carcass characteristics and haematological indices when compared with the control did not vary significantly. The serum cholesterol levels $(\mathrm{mg} / \mathrm{dl})$ in groups D $(101.40 \pm 4.13)$, E $(106.60 \pm 4.59)$ and $\mathrm{F}(100.20 \pm 9.83)$ were significantly lower $(\mathrm{p}<0.05)$ in comparison with the level in group C $(127.00 \pm 8.83)$. Groups E $(46.96 \pm 8.62 \mathrm{mg} / \mathrm{dl})$ and $\mathrm{F}(47.44 \pm 6.35 \mathrm{mg} / \mathrm{dl})$ had significantly $(\mathrm{p}<0.05)$ lower LDL-C compared with the control $(70.56 \pm 8.75 \mathrm{mg} / \mathrm{dl})$. Therefore, mixture of ginger, garlic and cinnamon may have no effects on the overall weight gain, carcass traits and haematological profiles but could decrease the risk of atherogenesis and CVD in broiler chickens.
\end{abstract}

DOI: $\underline{\text { https://dx.doi.org/10.4314/jasem.v24i5.12 }}$

Copyright: Copyright (C) 2020 Idoko et al. This is an open access article distributed under the Creative Commons Attribution License (CCL), which permits unrestricted use, distribution, and reproduction in any medium, provided the original work is properly cited.

Dates: Received: 20 March 2020; Revised: 16 April 2020; Accepted: 27 April 2020

Keywords: Cinnamon; ginger; garlic; spices; physicochemical

Meat plays an important role in the human diet. It is a good source of high-quality protein and serves as a vital source of beneficial fatty acids and a variety of micronutrients for optimal health (Laura, 2015). Fat is the richest dietary source of energy in meat and varies depending on the type of the meat (Higgs, 2019) among others. The type of fat, as well as the total fat content of meat is important to consider in terms of CVD, as not all fats are equal. Different fatty acids have different effects on blood cholesterol and risk of heart disease, some beneficial and some adverse. The fat content of cooked chicken varies depending on the bird's diet and other factors such as breed, portion and on whether it is cooked with the skin on or off (Farrell, 2013). Unlike most other meats, chicken meat can easily be enriched with several other important nutrients. For instance, Yu et al. (2008) showed that by adding $0.24 \mathrm{mg}$ of selenium (as organic selenium) per kilogram of feed, the selenium content of breast meat increased from $8.6 \mu \mathrm{g}$ to $41 \mu \mathrm{g} / 100 \mathrm{~g}$, which is more than 65 percent of the RDI thereby preventing Keshan's disease, a heart ailment in the young and cognitive decline in adults which are caused by selenium deficiency. Also some bioactive plant substances in animal nutrition have been reported to have beneficial effects which include the stimulation of appetite and feed intake, the improvement of endogenous digestive enzyme secretion, activation of immune responses and antibacterial, antiviral and antioxidant actions (Dorman and Deans, 2000; Hosseini-Vashan et al., 2012). Idoko et al. (2019) reports that combination of dried and pulverized garlic, ginger and pomegranate in ratio of $2: 2: 1$ respectively could suppress fat accumulation in broiler chickens, without affecting other carcass traits, lipid and red blood cell indices. Herbs and spices have been used since ancient times, not only as antioxidants and flavoring agents, but also for their antimicrobial activity against degradation induced by food borne pathogens and food spoilage bacteria (Nabavi et al., $2015)^{\mathrm{a}}$. Furthermore, plants are rich in different classes of antimicrobial substances acting as defence systems which offer protection against biotic (living) and abiotic (non-living) stresses (Nabavi et al., 2015) . This research was conducted to study the influence of a mixture of ginger, garlic and cinnamon on the physicochemical properties of broiler meat. 


\section{MATERIALS AND METHODS}

One hundred and fifty (150) at day-old broilers chickens were purchased from Chi Farms Limited Ibadan in Nigeria. Pelletized commercial Starter and Finisher feeds were bought from Dustinma Central Market. Dried garlic and ginger purchased from Dustinma Central Market were separately pulverised using clean mortar and pestle to pass through $0.5 \mathrm{~mm}$ mesh sieve. Cinnamon powder was obtained from Alhilal Islamic Chemist Store, Kastina city, Katsina State.

Feed formulation: The spices; cinnamon, garlic and ginger were thoroughly mixed in ratio of $4: 2: 1$ respectively. The mixed spices and Starter were mixed in a ratio of 2:98 receptively to formulate $2 \%$ mixedspices supplemented Starter. Also, 2\% mixed-spices supplemented Finisher was formulated using the same method.

The following feeds were then formulated for the experiment;

1. $0 \%$ mixed-spices supplemented Starter

2. $2 \%$ mixed-spices supplemented Starter

3. $0 \%$ mixed-spices supplemented Finisher

4. $2 \%$ mixed-spices supplemented Finisher

Experimental design and animal management: Starter phase: In this phase of the experiment, the 150 chicks were divided into groups $\mathrm{A}$ and $\mathrm{B}$ of 75 birds each and randomly assigned to diets 1 and 2 respectively.

Finisher phase: In the second (Finisher) phase of the experiment, group A in the first phase was sub-divided into groups $\mathrm{C}$ and D while group B in the first phase was subdivided into groups $\mathrm{E}$ and $\mathrm{F}$ as follows;

Group C was maintained on $0 \%$ mixed spices supplemented Starter and then $0 \%$ mixed-spices supplemented Finisher feeds (Control).

Group D was maintained on $0 \%$ mixed spicessupplemented Starter and then 2\% mixed spicessupplemented Finisher feeds.

Group E was maintained on $2 \%$ mixed spicessupplemented Starter and then 2\% mixed spicessupplemented Finisher feeds.

Group $\mathrm{F}$ was maintained on $2 \%$ mixed spices supplemented Starter and $0 \%$ mixed spicessupplemented Finisher feeds.

The broilers were kept in accordance with the method of Idoko et al. (2019). In this method, the birds were put in a warm $\left(35^{\circ} \mathrm{C}-38^{\circ} \mathrm{C}\right)$, appropriately ventilated and disinfected environment. After seven days of acclimatization to the experimental environment, the birds were maintained ad libitum on their respective experimental Starter feeds for three (3) weeks and Finisher feeds for another three (3) weeks. The birds received gumboro disease vaccines on the $10^{\text {th }}$ and $24^{\text {th }}$ days. Newcastle disease vaccine (Lasota strain) was administered on the $17^{\text {th }}$ and $31^{\text {st }}$ days.

Determination of feed intake and growth pattern: The quantity of feed left over was subtracted from the quantity of feed served on daily basis to determine the daily feed consumed. The average weekly feed consumptions were calculated from the daily consumptions. The change in weight was estimated by weighing the chicks at the commencement of the experiment and thereafter on weekly basis (Idoko et al., 2016).

Carcass performance: At the end of the feeding trial, 5 birds with the least standard deviation among them were selected from each group and starved for 12 hours, weighed after the fasting and sacrificed by severing the jugular vein. Blood was collected in sample tubes (EDTA-treated and untreated). The sacrificed birds were scalded and plucked. They were cut open and eviscerated. The dressing, carcass, giblets and fat pad percentages as well as percentage organ to body weight were then computed following the methods adopted by Isa (2018) as follows:

Dressing $\%=$ Carcass weight $/$ live weight $\times 100$

Giblets $\%=($ Liver+Gizzard+Heart $)$ weight $/$ Live weight $\times 100$

Abdominal fat pad $\%=($ Fat pad weight $/$ Live weight $)$ $\times 100$

$\%$ Liver $=$ liver weight $/$ carcass weight $\times 100$

$\%$ Heart $=$ Heart weight $/$ carcass weight $\times 100$

$\%$ Gizzard $=$ Gizzard weight $/$ carcass weight $\times 100$

Determination of lipid and haematological profile: Serum was processed from the blood in the plain tubes following the method of Akanji and Ngaha (1989). Serum lipid (Total cholesterol(TC), Triglyceride and HDL-C) concentrations were determined using lipid profile enzyme assay kits from Randox Laboratories Ltd. LDL-C was computed from the formula TC(TG/5 +HDL) (Friedewald et al., 1972) while VLDL was computed from; VLDL-C=Total triglycerides divided by 5 (Tietz, 1976). Atherogenic index and coronary risk index were computed from the determined lipid profiles (Kazemi et al., 2018); Atherogenic Index $(\mathrm{AI})=\mathrm{LDL}-\mathrm{C} / \mathrm{HDL}-\mathrm{C}$ Coronary risk index $(\mathrm{CRI})=(\mathrm{TC} / \mathrm{HDL}-\mathrm{C})$. The haematological parameters were determined in blood collected into EDTA-treated tubes at Federal Medical Centre, Katsina using automated haematology Analyser.

Statistical analysis: Results were expressed as means \pm SEM. Results obtained in the starter phase were subjected to Student t-test but to one-way ANOVA in the Finisher phase to assess statistical significance

IDOKO, AS; ZAHARADDEEN, A; IMAM, NU; NURA, S; ABDULAZEEZ, B; SUNDAY, H; UGWU, KU; OLAIYA, HA 
where $\mathrm{p}<0.05$ was considered significant. SPSS (16.0 version) was the statistical package program used for the analysis.

\section{RESULT AND DISCUSSION}

Figure 1 shows the result of the growth pattern of broiler birds fed diets supplemented with a mixture of ginger, garlic and cinnamon during the Starter phase. The weight of the birds fed diet 2 remained significantly lower $(\mathrm{p}<0.05)$ than that fed diet1 throughout the starter phase. Similarly, the average weekly weight gain in birds maintained on diet 2 differed significantly $(\mathrm{P}<0.05)$ when compared with average weekly weight gain in birds maintained on diet 1 (Table 1). There were no significant variations $(p>0.05)$ in the weight gain by the experimental birds during the finisher phase (Table 2). However, the chickens maintained on diets 2 and 4 (Group E) had a more steady linear increase in weight (Figure 2). The results of the evaluated carcass characteristics show that mixture of the spices had no significant $(\mathrm{p}>0.05)$ effects on them (Table 3). The lower weight gain by the group maintained on diet 2 during the starter phase could be due to the thermogenic and metabolicincreasing effects of the added spices. Ajoene, an organo-sulfur compound found in garlic is reported not only to exert inhibitory effect on adipogenesis, but to also induce apoptosis (Ambati et al., 2009). Zingibaine, a cysteine protease enzyme found in ginger degrades and mobilizes storage proteins and can also respond to abiotic and biotic stresses, such as heat shock, cold temperatures, and dehydration (Ha et al., 2012). Cinnamon has been shown to reduce some of the bad effects of eating high-fat foods helping in an overall weight loss plan. The anti-inflammatory and antibacterial properties of cinnamon can bring about loss of weight by promoting an overall healthy body that would process food better (Diana, 2016). Previously, Idoko et al. (2019) reported similar finding with combination of dried and pulverized garlic, ginger and pomegranate in ratio of 2:2:1 respectively. During the finisher phase, the birds might have acclimatized to the spices resulting in improved weight gain. This could explain why birds fed the supplemented diets during both the starter and finisher phases (Group E) and group fed the supplemented diets during the finisher phase (Group D) had significantly higher weight gain during the third week of the finisher period; the overall weight change did not significantly vary, though. This suggests that the anti-inflammatory, anti-fungal, antiviral, blood purifying effects of the spices under investigation manifest more in older birds thereby aiding in the digestion by increasing the motility of the intestinal tract as well as increasing gastro-intestinal enzyme secretions. This is consistent with the report by Diana
(2016) that cinnamon will not lead to long-term weight loss. The non-significant variation in the dressing code is understandable since the weight gains did not vary among the groups during the finisher phase of the experiment. The mixed spices may be neither hypertrophic nor hypotrophic as indicated by the nonsignificant variations in the percentage organ to body weight ratio.

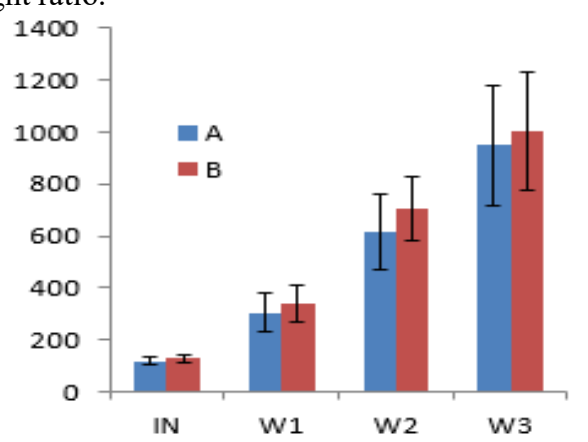

Fig 1: Growth pattern of broiler chicks fed diets supplemented with a mixture of ginger, garlic and cinnamon during the Starter phase IN: Initial weight; A: Group maintained on $0 \%$ mixed-spices supplemented Starter; B: Group maintained on 2\% mixed-spices supplemented Starter.

Table 1: Weight gain (g) by broiler chicks fed diets supplemented with a mixture of ginger, garlic and cinnamon during the Starter

\begin{tabular}{ll} 
& phase \\
\hline & Weight gain \\
\hline A & $274.26 \pm 20.23^{\mathrm{a}}$ \\
B & $235.15 \pm 15.55^{\mathrm{b}}$ \\
\hline
\end{tabular}

Values are expressed as mean of 5 determinations \pm SEM. Values along the same column with the same superscript are NOT significantly different $(P>0.05)$. A: Group maintained on $0 \%$ mixedspices supplemented Starter. B: Group maintained on 2\% mixedspices supplemented Starter.

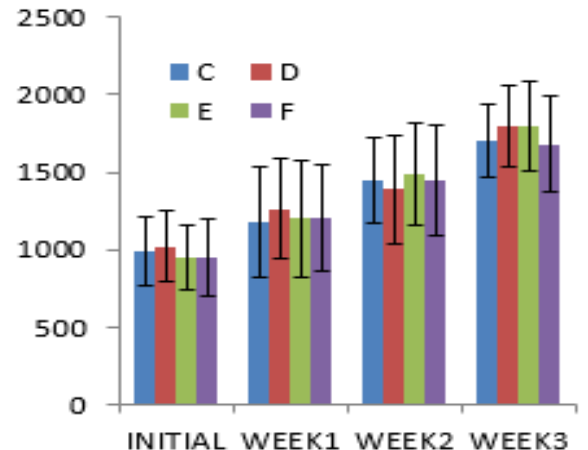

Fig 2: Growth pattern of broiler chickens fed diets supplemented with a mixture of ginger, garlic and cinnamon during the Finisher phase

Group C was maintained on 0\% mixed spices - supplemented Starter and then $0 \%$ mixed-spices -supplemented Finisher feeds (Control); Group D was maintained on $0 \%$ mixed spicessupplemented Starter and then $2 \%$ mixed spices-supplemented Finisher feeds.; Group E was maintained on $2 \%$ mixed spicessupplemented Starter and then 2\% mixed spices-supplemented Finisher feeds; Group F was maintained on $2 \%$ mixed spices supplemented Starter and $0 \%$ mixed spices-supplemented Finisher feeds. 
Table 2: Weight gain by broiler chickens fed diets supplemented with a mixture of ginger, garlic and cinnamon

\begin{tabular}{lllll} 
& C & D & E & F \\
\hline WG(g) & $242.31 \pm 4.97^{\mathrm{a}}$ & $282.46 \pm 15.04^{\mathrm{a}}$ & $260.14 \pm 81.11^{\mathrm{a}}$ & $236.67 \pm 24.29^{\mathrm{a}}$
\end{tabular}

Values are expressed as mean of 5 determinations \pm SEM. Values along the same row with the same superscript are NOT significantly different $(P>0.05)$

Table 3: Carcass traits of broiler chickens fed diets supplemented with a mixture of ginger, garlic and cinnamon

\begin{tabular}{lllll}
\hline & $\mathrm{C}$ & $\mathrm{D}$ & $\mathrm{E}$ & $\mathrm{F}$ \\
\hline Dressing\% & $68.62 \pm 2.064^{\mathrm{a}}$ & $67.63 \pm 1.52^{\mathrm{a}}$ & $67.35 \pm 1.39^{\mathrm{a}}$ & $66.1 \pm 1.22^{\mathrm{a}}$ \\
$\% \mathrm{~L} / \mathrm{CW}$ & $2.89 \pm 0.13^{\mathrm{a}}$ & $3.73 \pm 0.36^{\mathrm{a}}$ & $3.5 \pm 0.39^{\mathrm{a}}$ & $3.08 \pm 0.32^{\mathrm{a}}$ \\
$\% \mathrm{H} / \mathrm{CW}$ & $0.55 \pm 0.04^{\mathrm{a}}$ & $0.65 \pm 0.05^{\mathrm{a}}$ & $0.61 \pm 0.04^{\mathrm{a}}$ & $0.54 \pm 0.04^{\mathrm{a}}$ \\
$\% \mathrm{G} / \mathrm{CW}$ & $2.29 \pm 0.14^{\mathrm{a}}$ & $2.21 \pm 0.17^{\mathrm{a}}$ & $2.49 \pm 0.13^{\mathrm{a}}$ & $2.47 \pm 0.27^{\mathrm{a}}$ \\
$\% \mathrm{~F} / \mathrm{CW}$ & $1.33 \pm 0.08^{\mathrm{a}}$ & $1.49 \pm 0.22^{\mathrm{a}}$ & $1.51 \pm 0.23^{\mathrm{a}}$ & $1.84 \pm 0.45^{\mathrm{a}}$ \\
$\%(\mathrm{LHG}) / \mathrm{CW}$ & $5.73 \pm 0.27^{\mathrm{a}}$ & $6.59 \pm 0.48^{\mathrm{a}}$ & $6.6 \pm 0.46^{\mathrm{a}}$ & $6.09 \pm 0.52^{\mathrm{a}}$ \\
\hline
\end{tabular}

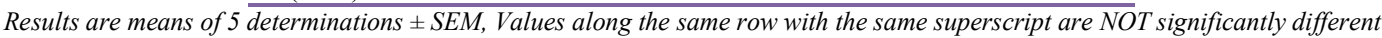
$(P>0.05)$, but are significantly different if the superscripts are different $(P<0.05)$.

Broiler chickens maintained on diets 2 and 4 (Group E) had significantly higher $(\mathrm{p}<0.05)$ triacylglycerol and VLDL-C but lower LDL-C compared with the group fed diets 1 and 3 (control). All the tested groups had significantly lower $(\mathrm{p}<0.05)$ total cholesterol (Table 4). The mixed spices caused no significant $(p>0.05)$ changes in the evaluated haematological profiles (Table 5). Assessment of lipid profiles is important because alteration in serum lipid profile such as increase in total cholesterol (TC), triacylglycerol (TAG), and low-density lipoprotein cholesterol (LDL-C), and reduction in high-density lipoprotein cholesterol (HDL-C) are key factors in cardiovascular disease progression. Atherogenic index (AI) (LDL-C/HDL-C) and coronary risk index (CRI) (TC/HDL-C) are even considered stronger markers for predicting the risk of atherosclerosis and coronary heart disease (Kazemi et al., 2018). In chickens, herpes virus infection of arterial smooth muscle cells has been shown to cause cholesteryl ester (CE) accumulation (Hsu et al., 1995), leading to atherosclerosis (Fabricant and Fabricant, 1999). The association of cytomegalovirus (CMV) infection in chickens with cardiovascular diseases has been reported (Cheng et al., 2009). The significantly lower LDL-C is instructive because it is the major source of lipids that accumulate in the atherosclerotic plaques (Summerhill et al., 2019). Atherosclerosis develops when lowdensity lipoprotein molecules (LDL) become oxidized (ldl-ox) by free radicals, particularly oxygen free radicals (ROS) (Jagdish, 2009). Therefore, supplementation with the spices particularly in the finisher phase could protect the birds from atherogenic and cardiovascular related problems. This could be achieved through; the antiviral and antibacterial activities of the spices which may confer protection against the herpes virus and cytomegalovirus infections. The antioxidant properties of the spices could also decrease the oxidation of LDL which is the major cause of atherosclerosis. In addition, the spices decrease the concentration of circulating LDL-C. Although the two groups respectively maintained on diets 2 and 4 (Group E) and 1 and 4 (Group F) had significantly lower LDL-C, inclusion of the mixed spices only in the Finisher may give better result in terms of protection against atherogenesis and CVD. This is so because Group E also had significantly higher TG and VLDL-C both of which are also factors in development of atherosclerosis and CVD. Plasma very low density lipoprotein (VLDL) had long been recognised as a useful parameter to infer the degree of fatness in chickens and decreasing its level, by any mean, causes decrease in abdominal fat in broiler chickens (Whithead and Griffin; Whithead et al., 1986). This is consistent with some other findings on the effect of some spices on the lipid profile (Utami et al., 2017; Puvača et al., 2015; Elbagir et al., 2013). However, Idoko et al. (2019) reported that combination of dried and pulverized garlic, ginger and pomegranate in ratio of 2:2:1 respectively may have no effect on the lipid profiles of broiler. Compared with the control, the spices had no significant effect on erythropoiesis as shown by the non-significant variations in haematological parameters.

Table 4: Lipid profiles of broiler chickens fed diets supplemented with a mixture of ginger, garlic and cinnamon

\begin{tabular}{lllll}
\hline & $\mathrm{C}$ & $\mathrm{D}$ & $\mathrm{E}$ & $\mathrm{F}$ \\
\hline TC(mg/dl) & $127.00 \pm 8.83^{\mathrm{b}}$ & $101.40 \pm 4.13^{\mathrm{a}}$ & $106.60 \pm 4.59^{\mathrm{a}}$ & $100.20 \pm 9.83^{\mathrm{a}}$ \\
TG(mg/dl) & $115.20 \pm 7.36^{\mathrm{a}}$ & $101.20 \pm 4.14^{\mathrm{a}}$ & $155.20 \pm 12.53^{\mathrm{b}}$ & $101.80 \pm 3.93^{\mathrm{a}}$ \\
HDL-C(mg/dl) & $28.40 \pm 1.86^{\mathrm{a}}$ & $31.20 \pm 2.03^{\mathrm{a}}$ & $28.60 \pm 2.40^{\mathrm{a}}$ & $32.40 \pm 5.72^{\mathrm{a}}$ \\
LDL-C(mg/dl) & $70.56 \pm 8.75^{\mathrm{a}}$ & $69.96 \pm 2.09^{\mathrm{a}}$ & $46.96 \pm 8.62^{\mathrm{b}}$ & $47.44 \pm 6.35^{\mathrm{b}}$ \\
VLDL-C(mg/dl) & $23.04 \pm 1.47^{\mathrm{a}}$ & $20.24 \pm 0.83^{\mathrm{a}}$ & $31.04 \pm 2.51^{\mathrm{b}}$ & $20.36 \pm 0.79^{\mathrm{a}}$ \\
AI & $2.79 \pm 0.55^{\mathrm{a}}$ & $2.27 \pm 0.14^{\mathrm{a}}$ & $1.77 \pm 0.48^{\mathrm{a}}$ & $1.56 \pm 0.24^{\mathrm{a}}$ \\
CRI & $4.62 \pm 0.66^{\mathrm{a}}$ & $3.93 \pm 0.16^{\mathrm{a}}$ & $3.87 \pm 0.47^{\mathrm{a}}$ & $3.24 \pm 0.29^{\mathrm{a}}$ \\
\hline
\end{tabular}

Results are means of 5 determinations \pm SEM, Values along the same row with the same superscript are NOT significantly different (P>0.05), but are significantly different if the superscripts are different $(P<0.05) . T C=$ total cholesterol; $T G=$ triglyceride; HDL-C $=:$ high density lipoprotein cholesterol; $L D L-C=$ low density lipoprotein cholesterol; $A I=$ atherogenic index; $C R I=$ cardiac risk index

IDOKO, AS; ZAHARADDEEN, A; IMAM, NU; NURA, S; ABDULAZEEZ, B; SUNDAY, H; UGWU, KU; OLAIYA, HA 
Table 5: Haematological indices of broiler chickens fed diets supplemented with a mixture of ginger, garlic and cinnamon during the finisher phase

\begin{tabular}{lllll}
\hline & C & D & E & F \\
\hline RBC $\left(10^{6} / \mu \mathrm{L}\right)$ & $2.16 \pm 0.24^{\mathrm{a}}$ & $1.96 \pm 0.10^{\mathrm{a}}$ & $2.24 \pm 0.14^{\mathrm{a}}$ & $2.32 \pm 0.13^{\mathrm{a}}$ \\
HGB $(\mathrm{g} / \mathrm{dL})$ & $8.60 \pm 0.37^{\mathrm{a}}$ & $7.98 \pm 0.22^{\mathrm{a}}$ & $9.03 \pm 0.65^{\mathrm{a}}$ & $9.38 \pm 0.49^{\mathrm{a}}$ \\
PCV (\%) & $28.10 \pm 1.10^{\mathrm{a}}$ & $27.02 \pm 1.02^{\mathrm{a}}$ & $30.13 \pm 1.61^{\mathrm{a}}$ & $31.28 \pm 1.32^{\mathrm{a}}$ \\
MCV (fL) & $129.00 \pm 2.58^{\mathrm{a}}$ & $134.68 \pm 3.89^{\mathrm{a}}$ & $133.43 \pm 0.66^{\mathrm{a}}$ & $134.60 \pm 1.55^{\mathrm{a}}$ \\
MCH (ps) & $39.92 \pm 0.44^{\mathrm{a}}$ & $41.28 \pm 1.28^{\mathrm{a}}$ & $40.08 \pm 0.56^{\mathrm{a}}$ & $40.30 \pm 0.90^{\mathrm{a}}$ \\
MCHC (g/dL) & $30.64 \pm 0.38^{\mathrm{a}}$ & $30.42 \pm 1.14^{\mathrm{a}}$ & $29.88 \pm 0.55^{\mathrm{a}}$ & $29.94 \pm 0.69^{\mathrm{a}}$ \\
WBC $\left(10^{6} / \mathrm{L}\right)$ & $92.04 \pm 1.07^{\mathrm{a}}$ & $92.05 \pm 0.97^{\mathrm{a}}$ & $89.7 \pm 1.36^{\mathrm{a}}$ & $90.42 \pm 1.88^{\mathrm{a}}$
\end{tabular}

RBC: red blood cells; HB: haemoglobin; PCV: Packed cell volume; $M C V:$ mean corpuscular volume; MCH: mean corpuscular haemoglobin; MCHC: mean corpuscular haemoglobin concentration; WBC: white blood cells

Conclusion: Having investigated broiler chickens fed diets supplemented with a mixture of ginger, garlic and cinnamon, it is our conclusion that mixture of the spices has no effects on the overall weight gain, carcass traits and haematological profiles but could decrease the risk of atherogenesis and CVD in broiler chickens.

\section{REFERENCE}

Akanji, MA; Ngaha, EO (1989). Effect of repeated administration of berenilonurinary excretion with corresponding tissue pattern in rats. Pharmacol Toxicol. 64: 272-275

Ambati, S; Yang, JY; Rayalam, S; Park, HJ; DellaFera, MA; Baile, CA (2009). Ajoene exerts potent effects in 3T3-L1 adipocytes by inhibiting adipogenesis and inducing apoptosis. Phytother Res. 23 (4): 513-518

Cheng, J; Ke, Q; Jin, Z; Wang, H; Kocher,O; Morgan, JP; Zhang, J; Crumpacker, CS (2009). Cytomegalovirus Infection Causes an Increase of Arterial Blood Pressure. PLoS Pathog. 5 (5).

Diana, W (2016). What's to know about cinnamon powder? https://www.medicalnewstoday.com , articles. 2016. Accessed Oct 23, 2019

Dorman, HJD; Deans, SG (2000). Antimicrobial agents from plants: Antibacterial activity of plant volatile oils. Journal of Appl Microbiol. 88: 308316

Elbagir, M; Nabiela, I; Hind, AA; Elagib, S; Abbas, A; Ginaw, TAN (2013). Effect of cinnamon and ginger compared to doxystin (antimicrobial drug) on serum lipid profile in broiler chicks. Online J. Anim. Feed Res. 3(1):58-61

Fabricant, CG; Fabricant, J (1999). Atherosclerosis induced by infection with Marek's disease herpesvirus in chickens. Am Heart J. 138 (5): 465468.
Farrell, D (2013). The role of poultry in human nutrition: Poultry Development Review http://www.fao.org/docrep/019/i3531e/i3531e02.pd $f$. Accessed 09 Jan., 2020

Friedewald, WT; Levy, RI; Fredrickson, DS (1972). Estimation of low-density lipoprotein cholesterol without the use of the preparative ultracentrifuge. Clin Chem. 18 (6): 499-502

Ha, M; Bekhit, AE; Carne, A (2012). Characterisation of commercial papain, bromelain, actinidin and zingibain protease preparations and their activities toward meat proteins. Food Chem. 134 (1):95-105

Higgs, J (2019). The changing nature of red meat: 20 years of improving nutritional quality. Trends Food Sci. Technol. 11:85-95

Hosseini-Vashan, SJ; Golian, A; Yaghobfar, A; Zarban, A; Afzali, N; Esmaeilinasab, P (2012). Antioxidant status, immune system, blood metabolites and carcass characteristic of broiler chickens fed turmeric rhizome powder under heat stress. Afr. J. Biotechnol. 11 (94): 1618-1625.

Hsu, HY; Nicholson, AC; Pomerantz, KB; Kaner, RJ; Hajjar, DP (1995). Altered cholesterol trafficking in herpes virus-infected arterial cells. Evidence for viral protein kinasemediated cholesterol accumulation. J Biol Chem. 270 (33): 19630-19637

Idoko, AS; Lawal, N. and Ilouno, EL (2016). Studies on the Oxidative Balance in Rats Maintained on Ripe Musaparadisiaca Peel. IJBcRR. 10 (3) 1-7

Idoko, AS; Zaharaddeen, AS; Nura, L; Sabiu, UA; Alao, SO; Idoko, I; Saidu, S (2019). Mixed-spices supplementation suppresses fat deposition and causes no alterations in lipid and red blood cell profiles in broiler chickens, FUDMA J. Sci. 3 (2): $288-294$

Isa, K.J.J (2018). Performance and Lipid Profile f Broilers Fed Two Medicinal Plants. M.Sc. Thesis, 
An-Najah National University, Nablus, Palestine. Retrieved July 14, 2018 from https://pdfs.semanticscholar.org/1f28/1abeab26b67 f644c651f1a0c3f164ac2ec18.pdf

Jagdish, K (2009). Causes, Symptoms, Pathophysiology and Diagnosis Of Atherosclerosis. Pharmacologyonline. 3:420-442

Kazemi, T;Hajihosseini, M; Moossavi, M; Hemmati, M; Ziaee, M. (2018). Cardiovascular Risk Factors and Atherogenic Indices in an Iranian Population: Birjand East of Iran. Clinical Medicine Insights. Cardiology.

https://www.ncbi.nlm.nih.gov/pubmed/29497341

Laura, W. (2015). The future of animal products in the human diet: health and environmental concerns in 2015 Symposium on meat, health and sustainability. Nutrition Society 2015.https://www.cambridge.org/core/services/aop -cambridgecore/content/view/7EE0FE146D674BB59D882BE A17461F1B/S0029665115004267a.pdf/role_of_red meat_in_the_diet_nutrition_and_health_benefits.p df.

Nabavi, SF; Lorenzo, AD; Izadi, M; Sobarzo-Sánchez, E; Daglia, M; Nabavi, SM (2015). Antibacterial Effects of Cinnamon: From Farm to Food, Cosmetic and Pharmaceutical Industries. Nutrients. 7: 7729$7748 b$

Nabavi, S.M; Marchese, A; Izadi, M; Curti, V; Daglia, M; Nabavi, S.F. (2015). Plants belonging to the genus Thymus as antibacterial agents: From farm to pharmacy. Food Chem. 173: 339-347a
Puvača, N; Kostadinović, L; Ljubojević, D; Lukač, D; Lević, J; Popović, S; Novakov, N; Vidovi B; Đuragić, O (2015). Effect of garlic, black pepper and hot red pepper on productive performances and blood lipid profile of broiler chickens. Europe. Pout. Sci. 79.

Summerhill, VI; Grechko, AV; Yet, S; Sobenin, IA; Orekhov, AN (2019). The Atherogenic Role of Circulating Modified Lipids in Atherosclerosis. Inter. J. Mol. Sci. 20 (14): 3561

Tietz, NW (1976). Fundamentals of clinical chemistry. WB Saunders Company. Washington D.C

Utami, MM. D; Pantaya, D; Agus, A (2017). Addition of Garlic Extract in Ration to Reduce Cholesterol Level of Broiler. The 2nd International Joint Conference on Science and Technology (IJCST) IOP Publishing IOP Conf. Series, Journal of Physics: $\quad$ Conf. 953. file:///C:/Users/SADIQ/Downloads/Addition of G arlic_Extract_in_Ration_to_Reduce_Cho.pdf

Whithead, C.C; Griffin, H.D (1984). Development of divergent lines of lean and fat broilersusing plasma low density lipoprotein concentration as a selection criterion: the first three generations. Br. Pout. Sci. 25: $573-582$.

Whithead, CC; Saunderson, CL; Griffin, HD (1986). Improved productive efficiency in genetically leanness broilers. Br. Pout. Sci. 27:162

Yu, DJ; Na, JC; Kim, SH; Kim, JH; Kang, GH; Kim, HK; Seo, OS; Lee, JC (2008). Effects of dietary selenium sources on the growth performance and selenium retention of meat in broiler chickens In Proceedings XIII World's Poultry Congress, 30 June-4 July, 2008. 